\title{
Problems of the Institutional-Legal and Organizational Provision of Systemic Innovation Policy: the Case of Ukraine
}

\author{
Inna Koblianska (iD https://orcid.org/0000-0002-7844-9786 \\ Ph.D., Associate Professor of Economics Department \\ Sumy National Agrarian University, Sumy, Ukraine \\ e-mail: koblyanska2@gmail.com
}

\section{Larysa Kalachevska (iD) https://orcid.org/0000-0001-7090-2518 Ph.D., Associate Professor of Management of Foreign Economic Activity and Eurointegration Department, Sumy National Agrarian University, Sumy, Ukraine e-mail: likalachevska@gmail.com}

\begin{abstract}
The article investigates the "systemic" dimension of the existing institutional-legal and organizational peculiarities of the innovation policy in Ukraine, based on the IS approach, which is seen as one of the main guidelines for the innovation policy formation, and, in particular, underlies the Ukrainian framework as well. The authors found that state strategic documents do not sufficiently reflect the systemic character of the NIS, nor do they place linkages or firms at the core of the national innovation system. Areas are determined where the innovation policy cannot be realized completely because of the current organization of activities and powers of the central executive authorities in this field, specifically: the impact on business, the formation of infrastructure, and the development of linkages. European countries' experience in the field of innovation policy implementation is explored, particularly, the creation and operating of the models of the national innovation agencies as well as the spectrum of their functions. Based on the European experience, it is proposed that a State Agency for Innovation and Development in Ukraine be created that will integrate the functions of regional project funding, provide advice, and realize the basic functions of the innovation intermediary.
\end{abstract}

Keywords: innovation, innovation system, innovation development institutions, innovation intermediary, innovation policy

JEL: O32, O38, H11, O52, O57 


\section{Introduction}

Innovation is one of the most important factors of competitiveness and economic growth, so the issues of stimulating innovation and providing innovation-based development are naturally at the center of attention of scientists around the world. The results of the latest research in this area convincingly prove that "innovation does not exist in isolation" (Klein Woolthuis et al. 2005), and the understanding of the systemic nature of innovation and the relevant processes of their development (Cooke 2001; Lundvall 2007) replaces the traditional economic paradigm, based on the linear nature of innovation development (Asheim \& Coenen 2006; Lundvall 2007). The systemic approach today is a key in the interpretation of innovation processes, as well as the appropriate policy (Fagerberg 2015; Kasych \& Vochozka 2017; Maloney 2017). The systemic nature of innovation processes is independent of the scale (Lundvall 2007) and appears at different levels of the study systems: regional (Cooke 2001; Isaksen 2001; Fedulova 2012), technological (Wieczorek \& Hekkert 2012), industry-specific (Jurkovičová et al. 2014), and national (Lundvall 2007; Kasych \& Vochozka 2017). Thus, the Innovation System (IS) approach underlies the formation of state innovation policies around the world (Verspagen et al. 2018), in particular, Ukrainian (On Approval 2009). However, recent research (Yegorov \& Ranga 2014; Khaustova 2016), as well as official statistics, shows the low efficiency of the innovation policy implemented in Ukraine, as the levels of innovation diffusion and implementation are low and limited by separate segments of the economy (Yegorov \& Ranga 2014). In this context, the problem of the misinterpretation of the essence and content of the IS approach in shaping, and in particular, implementing the innovation policy in Ukraine is evident. From this point of view, identifying the institutional-legal and organizational improvements of the Ukrainian innovation policy, which will contribute to the development of the fully fledged national innovation system and, accordingly, innovation-based economic growth, becomes important and relevant. It is also crucial, taking into account the necessity to fulfill Ukraine's obligations to the EU member states (Association 2014) and to achieve the target indicators identified in the "Strategy for Sustainable Development - Ukraine 2020" (On Strategy 2015).

Recent scholarly studies describe the state and tendencies of innovation development in Ukraine in a deep and detailed way (Yegorov \& Ranga 2014; Khaustova 2016), outlining the most important problems and ways to solve them, including those in the political decision-making area. The lack of structural reforms in the economy, the inadequate tax and regulatory legislation, the unfavorable business environment and policy, as well as the lack of R\&D funding, are the most important problems impeding innovation diffusion and knowledge-intensive economic growth (Yegorov \& Ranga 2014; Zakharchenko \& Kuznietsov 2017). In this context, researchers emphasize the need to strengthen the role of universities (Yegorov \& Ranga 2014; Zakharchenko \& Kuznietsov 2017), and to build links between firms, research institutes, and universities (Yegorov \& Ranga 2014; Kasych \& Vochozka 2017). It will contribute to the de- 
velopment of the Innovation Space, which is still "in its infancy", as part of the "Triple Helix" of the country's innovation development (Yegorov \& Ranga 2014, p. 21). The elaboration of a long-term strategy for the development of the National Innovation System (NIS) and the introduction of the NIS monitoring system, compliant with the methods used by OECD countries, are seen as prerequisites for the creation of a systemic innovation policy in Ukraine (Kasych \& Vochozka 2017). Pointing to the fact that there is a lack of a single structure responsible for the implementation of innovation policy in Ukraine, the dispersed functions of innovation regulation between ministries, their uncoordinated actions with the focus on the individual interests of the represented industries, and the excessive diversity and inconsistency of legislation in this area significantly hinder the country's innovation development (Jurkovičová et al. 2014; Yegorov \& Ranga 2014). Scientists, however, do not pay enough attention to the roots of these problems, nor ways to solve them. Thus, it is necessary to focus on the study of the conformity of the institutional-legal foundations and organizational peculiarities of the existing government innovation policy to the modern view of the innovation development process, in particular, its systemic attributes. This, in our opinion, critically determines the adequacy of policymaking, as well as its implementation.

\section{Acknowledging the "systemic" nature of the innovation process: an overview of Ukrainian legislation}

The terms used as well as the underlying theories and their interpretation, no doubt determine the policy's essence and content. The IS perspective presupposes the holistic view of the policy; thus its successful application requires the use of new "systemic tools" while creating, adapting and coordinating the policies, in particular, the strategic management of IS (Fagerberg 2015). The "Concept of the national innovation system development" (On Approval 2009) is the only document that defines a strategic and long-term (until 2025) vision of innovation development in Ukraine in the absence of an appropriate strategy. This document defines the structure of the NIS in Ukraine and the objectives and priority directions of its development aimed at promoting innovation. According to the Concept, the NIS in Ukraine is defined as "a set of legislative, structural and functional components (institutions) involved in the process of creating and applying scientific knowledge and technologies, and defining the legal, economic, organizational and social conditions for ensuring the innovation process" (On Approval 2009). This definition, in the first instance, does not correspond with the general basics of systems theory, where the system is seen as a set of interrelated elements, and the relationships determine the system attributes. Moreover, the given definition is not compliant with the IS concept, where the links between the system elements are of prime importance (Cooke 2001; Lundvall 2007; Fagerberg 2015; Autio et al. 2014). Thus, the 
existing legal basis does not reflect the IS idea sufficiently, in particular, concerning its systemic nature, which is actually formal with regard to the NIS development.

The IS approach requires a wider interpretation of innovation as a complex process (Klein Woolthuis et al. 2005), "encompassing the discontinuity in the technical characteristics or in the use of a new product, and the introduction, diffusion, and adaptation of a new artefact" (Lundvall 2007, p. 9). This process is non-linear and interactive in character, and it involves actors (firms (Klein Woolthuis et al. 2005, p. 609) interacting with different organizations (research institutes, consumers, government, financial organizations) under the framework of existing institutions (intellectual property rights, regulation, culture) (Klein Woolthuis et al. 2005, p. 609). Thus, innovation is a result of entrepreneurship, synergy, and firms' interactions, all of which ensure the joint interactive learning process (Cooke 2001; Lundvall 2007). This broad definition determines the elements and structure of the NIS (Wieczorek A.J. \& Hekkert 2012), where the firm is at the core (Lundvall 2007). According to the Concept, the NIS in Ukraine consists of the following subsystems: "state regulation, education, knowledge generation, an innovation infrastructure, and production (organizations and enterprises that produce innovative products and provide services and/or are consumers of technological innovations)." When looking at the elements of the last subsystem, it becomes evident that the NIS in Ukraine appears abstractly as a separate structure, narrowed by the processes of technology (new products), creation and use. This contradicts the broad understanding of innovation, which is seen as a result of joint interactive learning, involving society as a whole and existing institutions. Moreover, as "the solution to the problem of the NIS's development ... needs to ensure the coordination of the executive authorities and public and scientific institutions..." (On Approval 2009), so the firm's exclusion is evident when formulating the conceptual vision of innovation policy in Ukraine. The above-mentioned extract highlights the fragmentation and even irrelevancy of the Concept provisions in view of the IS approach. This places in question the ability to reach the set target indicators (On Approval 2009), namely: an increase in the share of innovative products in GDP growth up to $30 \%$; an increase in the share of innovative products in the total volume of manufactured products to $50 \%$, etc. The latest official statistics data confirm this view (Chart 1).

Commenting on the presented data (Chart 1), one should emphasize the general negative dynamics of innovation processes in the country over the past 17 years. Specifically, the share of innovation products in GDP has a steady tendency to decrease, and in 2015 (the latest data) it is even less than 1\%. The reduction in the share of innovative products in the total volume of manufactured goods is even more rapid, declining from almost $9.4 \%$ to $0.7 \%$ in 2017 . The expenditures of industrial enterprises related to the introduction of innovation are slightly higher in 2017 compared with 2000, in spite of the steady growth trends during the study period. The given national statistical data to some extent correlates with the Innovation Index dynamics, calculated by the European Commission (Innovation 2018). The Index reduction during 2010-2017 is a general tendency. However, the improvement in human resources and research system attractiveness, the IPR upturn, as well as the better impact on employment in the innovation 
sector caused a significant increase in 2017 compared to 2016. At the same time, many issues became substantially worse in 2017 compared to 2010, namely: the environment conducive to innovation, R\&D financing and support, and firms' investment, links, innovators, and impact on commodity turnover. The present data reveal the "systemic" (Klein Woolthuis et al. 2005; Wieczorek \& Hekkert 2012) and "transformational" (Raven \& Walrave 2018) failures of the existing innovation policy, which are, to some extent, the result of the formal and irrelevant interpretation of its systemic dimension (as shown above). The latter requires an urgent need for reforms in this area.

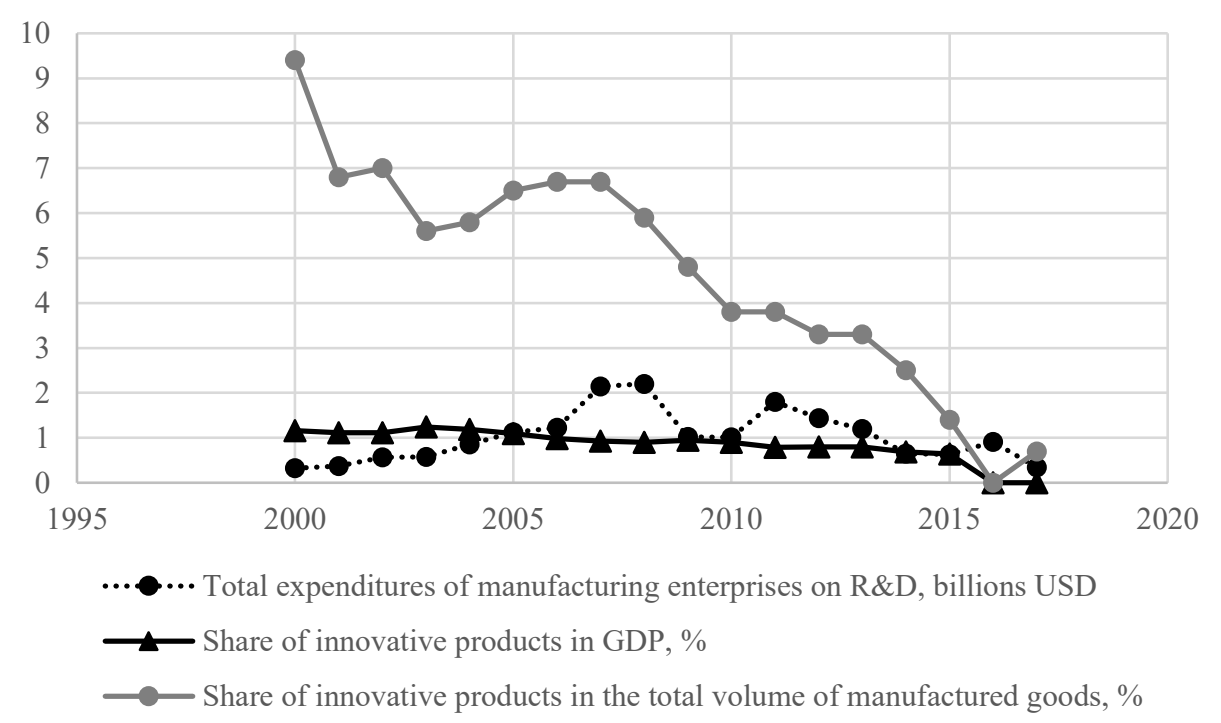

Chart 1. Innovation development trends in Ukraine

Source: State Statistics Service of Ukraine, www.ukrstat.gov.ua (accessed: 10.09.2018).

Innovation as a comprehensive category embraces all components of the process of technological change: recognizing the need and problem of determining new development ideas, finding solutions to existing problems, implementing new solutions and technological options, and their wider dissemination (Cooke 2001). Thus, an effective innovation policy requires the close coordination of various policies, as well as the development of new forms of governance and knowledge that make them possible (Fagerberg 2015). Ultimately, there is a need for a transition from a "scientific" and "technological" policy to a holistic one, i.e., an "innovation" policy (Lundvall 2007:6). The latter expands traditional areas of policy application, with particular emphasis on the linkages building and enhancing users' ability to adapt and apply the innovations (Lundvall 2007). 


\section{Organizational peculiarities of implementing the innovation policy in Ukraine}

It is obvious that an insufficient understanding of the complex nature of innovation and the systemic attributes of the innovation process have led to the delineation of policies in the field of education, as well as scientific, technical and innovation activities, and technology transfer. While different laws regulate these areas, a single body - the Ministry of Education and Science of Ukraine (MESU) - governs them, however (Regulation 2014). Thus, relevant laws determine the role, functions, and tasks of the Ministry in the specified areas (Table 1).

Table 1. Functions of the Ministry of Education and Science of Ukraine as a central executive body responsible for the formation and implementation of the scientific, scientific-technical, innovation and technology transfer policies

\begin{tabular}{|c|c|}
\hline Legal act & Functions (certain tasks) \\
\hline $\begin{array}{l}\text { On Innovation } \\
\text { Activity (2002) }\end{array}$ & $\begin{array}{l}\text { - Regulating activities of specialized state innovative financial and credit } \\
\text { institutions (SIFCI) supporting the innovative programs and projects (the } \\
\text { creation and normative regulation of activities); } \\
\text { Managing innovative projects (registration, competitive selection, exper- } \\
\text { tise); } \\
\text { Monitoring and forecasting, and identifying priority directions in the field } \\
\text { of innovation development; } \\
\text { the formation of innovative programs, determining the amount of state } \\
\text { budget funds for their financing, etc. }\end{array}$ \\
\hline $\begin{array}{l}\text { On State Regu- } \\
\text { lation of Activ- } \\
\text { ity in the Field } \\
\text { of Technology } \\
\text { Transfer (2006) }\end{array}$ & $\begin{array}{l}\text { - Governance in the field of technology transfer (keeping track of technol- } \\
\text { ogies, control over the transfer of property rights for state-financed tech- } \\
\text { nologies, determination of the ways to use modern technologies, moni- } \\
\text { toring and analysis); } \\
\text { - Facilitating technology transfer (infrastructure development, including } \\
\text { regional centers; investment attraction), etc. }\end{array}$ \\
\hline $\begin{array}{l}\text { On Scientific and } \\
\text { Scientific-Technical } \\
\text { Activity (2015) }\end{array}$ & $\begin{array}{l}\text { - Establishing a national system of scientific and technical information, and } \\
\text { its governance; } \\
\text { - Governance of the system of scientific and scientific-technical expertise; } \\
\text { - International scientific and technical cooperation (coordination, coopera- } \\
\text { tion agreements, support of cooperation, communications); } \\
\text { - Public requesting for the most important scientific and technical research } \\
\text { and products, their financial support; } \\
\text { - Financial support of scientific and technical activities of higher educa- } \\
\text { tional institutions that belong to the sphere of the Ministry's regulation; } \\
\text { - Keeping track of R\&D activities, etc. }\end{array}$ \\
\hline
\end{tabular}

Source: authors' generalization.

The data presented in Table 1 show that the functions of the government structure which is responsible for the formation and implementation of the scientific, scientific-technical, innovation and technology transfer policies are comprehensive. They cover the creation of an appropriate information space (system of scientific-technical and technology information), the formation of a favorable organizational environment (the development of infrastructure for promoting innovation), funding, and the formation 
of the basis for the policy and legislation improvement (through forecasts, analytical studies, and prioritization). At the same time, although authorized to implement these complex functions, the Ministry of Education and Science is not able to facilitate the implementation and dissemination of innovations enough as, according to its powers (Regulation 2014), it should not pursue issues of entrepreneurship and economic development. It questions the ability of the MESU to provide a fully-fledged innovation policy single-handedly, as the latter aimed, first of all, at "the creation of socio-economic ... conditions for the effective reproduction, development, and use of the country's scientific-technical potential, ensuring the introduction ... of technologies, and the production and sale of new types of products" (On Innovation 2002, Art. 3) and where "the effective use of market mechanisms for the promotion of innovation activities, and support of entrepreneurship in the science-production area" is one of the first principles (On Innovation 2002).

Additionally, one should emphasize the limited influence of the MESU on the development of innovation infrastructure, in particular, from the point of view of establishing and funding relevant organizations and structures. According to the law (Budget 2010), the implementation of investment programs and regional development projects, as well as the creation of industrial and innovation parks infrastructure, are financed through the State Fund for Regional Development (SFRD) (Budget 2010, Art. 24-1), under the control of the Ministry of Regional Development, Construction, Housing and Communal Services (Some Issues 2015). It is also difficult to overestimate the role of an advisory activity in the building of linkages and strengthening the business entities' capacity to implement innovation. The current legislation guarantees public support for the provision of such services for agricultural producers by suitably certified advisers, expert-advisers and advisory service institutions (On Agricultural 2004). At the same time, the Ministry of Agrarian Policy and Food of Ukraine (MAPFU) is authorized to form the state policy in the field of advisory activities, to develop the relevant national programs, to ensure the normative and methodological support, as well as to regulate the training, certification, and registration of advisers (On Agricultural 2004).

Based on the above, the incompleteness of the coverage of important NIS components under the control of a responsible agency is evident. Specifically, firms, infrastructure, and linkages remain out of the influence of the Ministry of Education and Science. In addition, one should point out the constrained ability of the MESU to govern the funding of innovation projects (Table 2).

The data provided (Table 2) suggest that the Ukrainian government has created a sufficient number of funds to finance innovation as well as to support business and entrepreneurship. At the same time, there are many unresolved issues related to the functioning of these funds. Firstly, there is the obvious similarity in the established funds' functions and tasks, albeit that different ministries control them (often in violation of the current legislation). Specifically, the Ministry of Economic Development and Trade controls the activities in the area of funding innovative projects through the SIFCI, which reports to this Minis- 
try (Issues 2000), contrary to the Law (On Innovation 2002) (see Table 1). Another problem lies in insufficient financing, as most of the Funds did not receive public finances for 2018. It puts into question the reasonability of the creation of the FID. Noting the absence of the relevant legislative bases for the FID's functioning, as of the middle of the $3^{\text {rd }}$ quarter of 2018, its creation seems to be nothing more than empty words, aimed at strengthening political power and position, rather than facilitating the development of innovation.

Table 2. State funds to support innovation and entrepreneurship

\begin{tabular}{|c|c|c|c|}
\hline $\begin{array}{l}\text { Fund title } \\
\text { (Legal act) }\end{array}$ & Functions & Governing body & $\begin{array}{l}\text { State budget } \\
\text { expenses for } \\
2018, \text { mln. UAH }\end{array}$ \\
\hline $\begin{array}{l}\text { State innovative financial } \\
\text { and credit institution } \\
\text { (SIFCI) http://difku.gov.ua/ } \\
\text { (accessed: 10.09.2018) } \\
\text { (Issues 2000) }\end{array}$ & $\begin{array}{l}\text { Financial support of business } \\
\text { projects within the framework } \\
\text { of state innovation policy }\end{array}$ & $\begin{array}{l}\text { the Ministry } \\
\text { of Economic } \\
\text { Development and } \\
\text { Trade of Ukraine } \\
\text { (MEDTU) }\end{array}$ & 100 \\
\hline $\begin{array}{l}\text { Ukrainian fund for entre- } \\
\text { preneurship support } \\
\text { http://ufpp.gov.ua } \\
\text { (accessed: 10.09.2018) } \\
\text { (On Ukrainian 1995) }\end{array}$ & $\begin{array}{l}\text { Training, consulting, guaran- } \\
\text { tee, preferential financial and } \\
\text { credit support for SMEs }\end{array}$ & MEDTU & - \\
\hline $\begin{array}{l}\text { State innovative non-bank } \\
\text { financial-credit institution } \\
\text { "Fund of small innovative } \\
\text { business support" (FSIBS) } \\
\text { (On Creation 2011) }\end{array}$ & $\begin{array}{l}\text { State support for innovation } \\
\text { implementation, especially for } \\
\text { small entrepreneurs }\end{array}$ & MESU & - \\
\hline $\begin{array}{l}\text { Fund of innovation } \\
\text { development (FID)* }\end{array}$ & Not specified & $\begin{array}{l}\text { The Cabinet } \\
\text { of Ministers } \\
\text { of Ukraine }\end{array}$ & 50 \\
\hline
\end{tabular}

* The creation of FID have been announced in 2018.

Source: authors' generalization.

When analyzing the financial dimensions of the innovation policy's implementation, one cannot ignore that the amount of public expenses allocated to SIFCI is three times less than the finances under the program "State support of technological innovations for industrial development" (300 mln. UAH, controlled by the MEDTU), and 62.5 times less than the financial resources allocated under the programs of state support for business in the agro-industrial complex and certain branches of agriculture $(6250 \mathrm{mln}$. $\mathrm{UAH}$, controlled by the MAPFU), as well as 60 times less than the amount budgeted for the SFRD (6000 mln. UAH, controlled by the Ministry of Regional Development, Construction, Housing and Communal Services) (On State Budget 2018). Consequently, the financial resources of these funds form the potential for the innovative development of all industries and regions in the country. However, the dispersion of these financial resources across different programs and government bodies impedes their efficient use in supporting innovative economic growth. In particular, experts point out that the projects implemented via the SFRD during 2015-2017 did not have a direct impact on re- 
gional business competitiveness and were, on the whole, ineffective in terms of achieving regional development goals (Report 2018). This illustrates the preservation of the tradition to make policy decisions based on business and political oligarchy interests rather than the social and economic interests of society (Hladchenko \& Pinheiro 2018).

Summarizing the above, it is necessary to point out that the current distribution of powers among governing authorities in the field of innovation policy implementation is not entirely adjusted. The key activities conducive to innovation development are scattered between different ministries and departments, creating a field for the spread of corruption and related offenses. It complicates the establishment of strong links and relationships of trust between the business environment and the authorities, as well as the state-controlled institutions, including the educational and research ones, thus reducing the government's influence on innovation processes and their development (Yegorov \& Ranga 2014). The solution to this problem requires significant institutional and organizational changes in the governance of innovation processes.

\section{The role of innovation intermediaries in strengthening the NIS}

The innovation system is self-organizing and co-evolving (Lundvall 2007), but the functions of institutions and the actors shaping it are decisive for its operation (Martin \& Scott 2000). In this context, increasing learning and innovation capacity means not only spending more resources on education and research, but also creating a wide range of institutions to support interactive learning (Cooke 2001; Lundvall 2007) and knowledge dissemination (Feinson 2003) in all parts of society, including individual families, communities, firms, and organizations. More attention should be focused on the processes of communication and cooperation between innovation actors, where economically useful knowledge is created and applied (Lundvall 2007). The coordination of market and non-market agents (Maloney 2017) and public and private actors (Coenen et al. 2016) through the formation of appropriate networks (Feinson 2003), is necessary to ensure the application and diffusion of innovation. Such networks do not appear automatically but require state incentives to create formal and informal institutions that facilitate the exchange of information, training and advisory activities, subcontracting, standards development, etc. (Feinson 2003). Thus, the state's function of the formation of links and relationships becomes of critical importance. Klerkx \& Leeuwis (2009) argue that the state could realize its coordinating role through the creation of innovation intermediaries. Innovation intermediaries are important elements of the functioning of an effective innovation system, as they support companies and provide knowledge and technology flows between science and business (Daniluk 2017). At the same time, the functions and organizational forms of such organizations are manifold, represented by business and innovation centers, 
non-bank financial institutions, etc. (Daniluk 2017, 129). The government's leading role in the creation of innovation intermediaries is due to the complexity of ensuring the self-sufficiency of demand articulation and network formation activities, the catalyzing role of intermediaries, and the need to be neutral yet compliant with the state's objectives while supporting the innovators (Klerkx \& Leeuwis 2009). The existing state funding institutions, advisory organizations in agriculture, as well as systems of technological and scientifical information, present only certain functions of an innovation intermediary organization; the single structure approach is absent in Ukraine. Certain networks of business and SME development organizations, supported by international institutions (in particular, "UnlimitUkraine"1, "EU4business"2) partially deal with issues of innovation development as well. In this context, the creation of a single body responsible for implementing the state innovation policy is crucial for the efficient functioning of the NIS in Ukraine. It will ensure a single vision and maintain basic goals and principles at all stages of the innovation process. Given the variety of possible organizational forms and functions of innovative intermediaries (Daniluk 2017; Klerkx \& Leeuwis 2009), it is advisable to investigate the European experience in this area, especially in view of Ukraine's European integration commitment.

\section{EU countries' experience in implementing the innovation policy}

A state-reporting agency responsible for implementing the innovation policy has been established in almost every EU country; however, they differ in the organizational, legal and ownership forms, as well as their activities. Most of them provide the entire spectrum of functional activities within the IS framework (e.g. business support, the development and dissemination of knowledge, demand articulation, funding, and the innovation policy formation (Wieczorek \& Hekkert 2012), thus acting as innovation intermediaries. Therefore, a close study of the organizational and legal bases, as well as the functions of such agencies, is expedient in order to determine the model that will best suit Ukraine.

Analysis of the information presented on the agencies' official web pages allows us to distinguish several models, namely: 1) The Ministries conducting educational and economic policy jointly create and control the agency's activities (Table 3); 2) The agency primarily reports to the Ministry responsible for the economic policy (Table 4); 3) The agency mainly reports to the Ministry responsible for the educational policy; and others.

1 http://unlimitukraine.com.ua/ (accessed: 10.09.2018).

2 http://www.eu4business.eu/uk/smeprojects (accessed: 10.09.2018). 
Table 3. National agencies of innovation development under the joint control of Ministries, responsible for the educational and economic policy

\begin{tabular}{|c|c|c|c|c|c|c|c|c|c|c|c|c|c|}
\hline \multirow[b]{2}{*}{$\begin{array}{c}\text { Agency } \\
\text { (country, web-page) }\end{array}$} & \multicolumn{13}{|c|}{ Activities performed } \\
\hline & 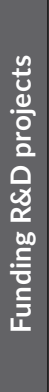 & 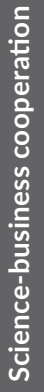 & 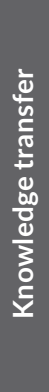 & $\begin{array}{l}\text { 음 } \\
\text { 음 } \\
\text { 임 } \\
\text { 흥 }\end{array}$ & 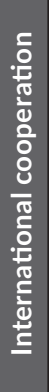 & 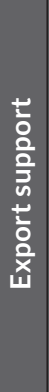 & $\begin{array}{l}\frac{t}{2} \\
\text { 을 } \\
\text { 을 } \\
\text { ய } \\
\text { u }\end{array}$ & 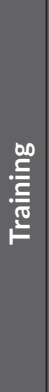 & 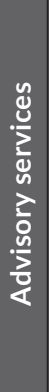 & 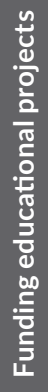 & 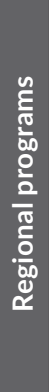 & 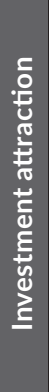 & 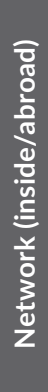 \\
\hline $\begin{array}{l}\text { ANI (Portugal, www.ani.pt } \\
\text { (accessed: 5.09.2018)) }\end{array}$ & + & + & + & + & + & & & & & & & & \\
\hline $\begin{array}{l}\text { Luxinnovation (Luxembourg, } \\
\text { www.luxinnovation.lu/ } \\
\text { (accessed: } 5.09 .2018 \text { ) }\end{array}$ & & + & + & + & + & & + & + & + & & & + & \\
\hline $\begin{array}{l}\text { MITA (Lithuania, https://mita.Irv.It } \\
\text { (accessed: 5.09.2018) }\end{array}$ & + & + & + & + & + & & + & + & + & & & + & \\
\hline $\begin{array}{l}\text { Innosuisse (Switzerland, www.innosu- } \\
\text { isse.ch (accessed: 5.09.2018) }\end{array}$ & + & + & + & & & & + & + & + & & & & $+/+$ \\
\hline 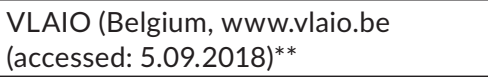 & + & + & & + & & & + & & & + & & & + \\
\hline
\end{tabular}

** A single department is responsible for economic development, research and scientific policies Source: authors' investigation.

The given data (Tables 3 and 4) show that most innovation agencies in EU countries primarily report to the Ministry that conducts economic policy. The functions of such organizations are quite broad and cover, in particular, training and consulting services for business, the development of science-business cooperation, the funding of business innovative projects, as well as the promotion of innovation and regional policy, etc. These organizations tend to have an extensive network within the country and even abroad (for example, in Finland, Estonia, Ireland, Italy, Spain, Croatia, and Switzerland).

The number of organizations created by the Ministry responsible for the educational policy is limited, as are their functions. For instance, the Danish Agency for Institutions and Educational Grants ${ }^{3}$ is responsible only for the promotion policy and for funding educational programs. Innovation Fund Serbia ${ }^{4}$ is empowered to finance R\&D and to attract investments.

3 https://ufm.dk/en/the-ministry/organisation/danish-agency-for-institutions-and-educational-grants/ (accessed: 2.09.2018).

4 http://www.innovationfund.rs/ (accessed: 2.09.2018). 
Table 4. National agencies of innovation development under the control of the Ministry conducting economic policy

\begin{tabular}{|c|c|c|c|c|c|c|c|c|c|c|c|c|c|}
\hline \multirow[b]{2}{*}{$\begin{array}{c}\text { Agency } \\
\text { (country, web-page) }\end{array}$} & \multicolumn{13}{|c|}{ Activities performed } \\
\hline & 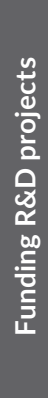 & 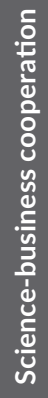 & 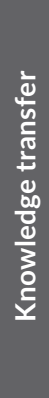 & 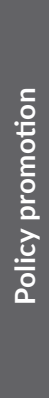 & 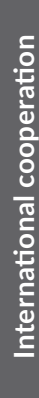 & 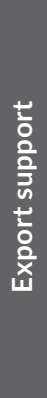 & $\begin{array}{l}\stackrel{ }{\circ} \\
\frac{0}{0} \\
\frac{0}{3} \\
\sum_{u}\end{array}$ & $\frac{\text { on }}{\frac{5}{5}}$ & 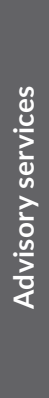 & 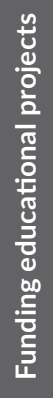 & 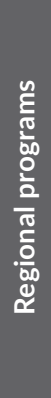 & 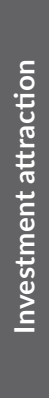 & 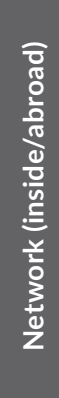 \\
\hline $\begin{array}{l}\text { CDTI (Spain, www.cdti.es/ } \\
\text { (accessed: 5.09.2018) }\end{array}$ & + & & + & + & + & & & & & & & & $+/+$ \\
\hline $\begin{array}{l}\text { ENEA (Italy, www.enea.it } \\
\text { (accessed: 5.09.2018) }\end{array}$ & + & + & + & + & + & & & & + & & + & & $+/+$ \\
\hline $\begin{array}{l}\text { HAMAG-BICRO (Croatia } \\
\text { www.investcroatia.hr/ } \\
\text { (accessed: } 4.09 .2018 \text { ) } \\
\end{array}$ & + & + & & & & & + & & + & + & & + & $+/+$ \\
\hline $\begin{array}{l}\text { NRDI Office (Hungary, } \\
\text { www.nkfih.gov.hu/the-office/ } \\
\text { (accessed: 3.09.2018) }\end{array}$ & + & & & + & + & & & & & + & & & \\
\hline $\begin{array}{l}\text { Netherlands Enterprise } \\
\text { Agency, www.english.rvo.nl } \\
\text { (accessed: 3.09.2018) }\end{array}$ & + & + & + & + & + & & & & & & & + & + \\
\hline $\begin{array}{l}\text { Slovak Innovation and Energy } \\
\text { Agency, www.en.siea.sk/ } \\
\text { (accessed: } 3.09 .2018 \text { ) }\end{array}$ & & + & + & + & + & + & & + & + & & + & + & \\
\hline $\begin{array}{l}\text { SPIRIT (Slovenia, } \\
\text { www.spiritslovenia.si } \\
\text { (accessed: 2.09.2018) }\end{array}$ & & + & + & + & + & + & + & + & + & & & + & \\
\hline $\begin{array}{l}\text { FFG* (Austria, www.ffg.at } \\
\text { (accessed: } 2.09 .2018 \text { ) }\end{array}$ & + & + & & + & + & & & & + & + & & & \\
\hline $\begin{array}{l}\text { Agency for Entrepreneurship } \\
\text { and Innovation (the Czech Re- } \\
\text { public, www.agentura-api.org } \\
\text { (accessed: } 2.09 .2018 \text { ) }\end{array}$ & + & & & + & + & & + & + & + & & & + & \\
\hline $\begin{array}{l}\text { Business Finland (Finland, } \\
\text { www.businessfinland.fi } \\
\text { (accessed: } 2.09 .2018 \text { ) }\end{array}$ & + & + & + & + & + & + & + & & & & & & $+/+$ \\
\hline $\begin{array}{l}\text { Enterprise Estonia (Estonia, } \\
\text { www.eas.ee (accessed: } \\
\text { 2.09.2018) }\end{array}$ & + & & & & + & + & & + & + & & + & & $+/+$ \\
\hline $\begin{array}{l}\text { Enterprise Ireland (Ireland, } \\
\text { www.enterprise-ireland.com } \\
\text { (accessed: } 2.09 .2018 \text { ) }\end{array}$ & + & + & + & + & + & + & + & + & + & & & & $+/+$ \\
\hline
\end{tabular}




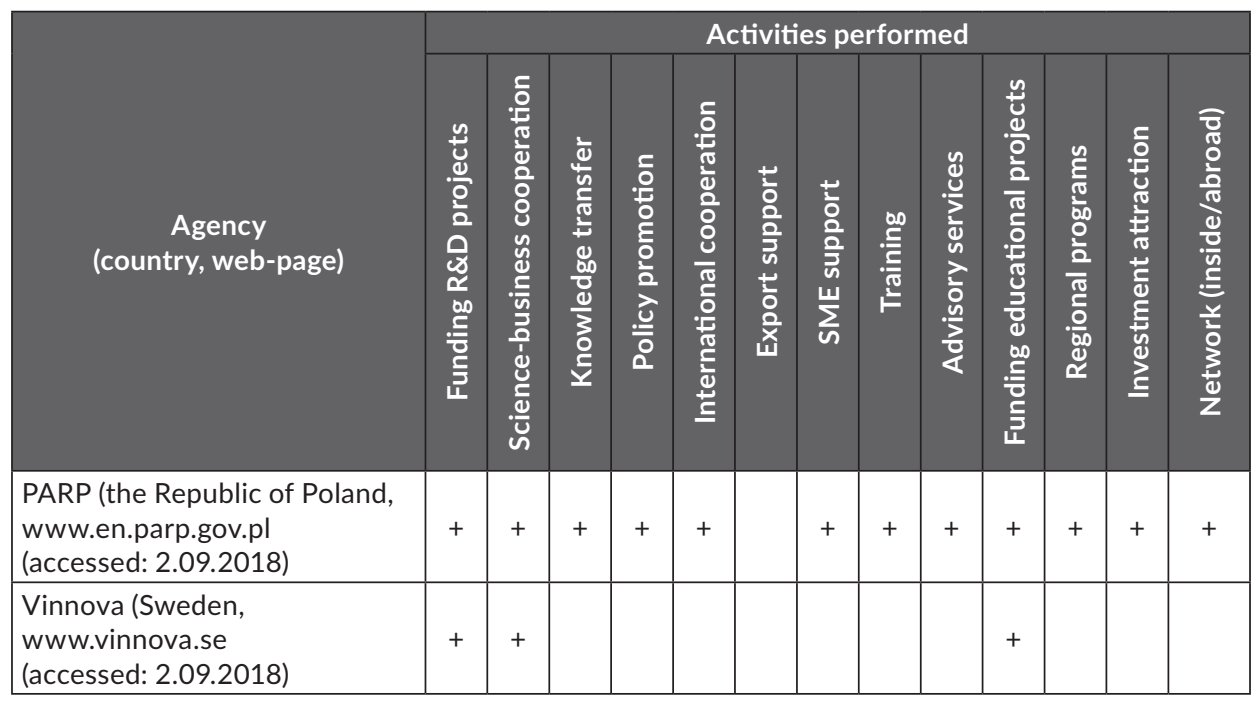

* also created with the participation of the Ministry responsible for transport, innovation and technology policies

Source: authors' investigation.

In some countries, there is no single agency, but separate organizations operate which report to the bodies responsible for the educational policy and the economic development policy. The Research Council of Norway reports to the Ministry responsible for the educational policy and deals with funding innovative projects, funding educational projects, promoting education policy, science, and business cooperation, international cooperation issues, attracting investment and it has a well-developed network of offices. Another organization - Innovation Norway - reports to the Ministry responsible for economic policy, and implements activities aimed at supporting all stages of the innovation process (except for financing educational and regional projects) and attracting investment. This Ministry also has an extensive network within the country and abroad. The Ministry of Education, Science, and Culture in Iceland coordinates the activities of "Rannis". The organization is responsible for funding innovative projects, including educational and scientific institutions' R\&D, policy promotion, attracting investment, and international cooperation. On the other hand, the Ministry of Industry and Innovation empowers Innovation Center Iceland to promote science and business cooperation, to provide knowledge transfer to companies, to support SMEs, to provide training and consulting, and to attract investments.

The intermediary organizations operating in Germany, France, the United Kingdom, and Turkey have a slightly different model. For instance, the German infrastructure for promoting innovation is extensive and well developed. It involves several dozen organizations that are both private (Project Management Jülich) and public-private (The High-Tech Gründerfonds, German Center for Research and Innovation). These 
organizations support innovators and research institutions, actively collaborate with the government, research and business entities, and give full-fledged support to innovation and related policy development. The State Financial Institution "Bpifrance" supports innovation diffusion and implementation in France, ensuring R\&D funding and international cooperation, assisting export-oriented companies and SMEs, promoting regional development projects and it also attracts investments. Innovate UK, as a non-departmental public body, reports to the Department for Business, Energy and Industrial Strategy, which coordinates the activities of 14 different ministries in the UK. The organization promotes innovation development through financing R\&D, strengthening science-business cooperation, and ensuring the transfer of knowledge to companies. The TTGV is a non-profit innovation intermediary organization in Turkey, operating on the basis of a public-private partnership. It gives full-fledged support to innovation development and appropriate policy, excluding the funding of educational projects.

Given the existing EU experience, it makes sense to establish an appropriate state-coordinated agency in Ukraine in order to provide an innovation-based development of society. This institution should, in our opinion, ensure the efficient implementation of policies in the field of innovation and entrepreneurship as well as regional development, since they are interconnected. The organizational peculiarities and the set of its functions are described below.

\section{The organizational and functional peculiarities of the State Agency for Innovation and Development in Ukraine}

The creation of a single body responsible for the implementation of innovation policy should ensure the observance of joint principles while implementing publicly funded projects, in particular:

- the focus on innovation (interpreted in a broad context as an orientation towards the use of new knowledge, and technical, organizational and technological solutions, as well as strengthening the ability of firms and communities to learn and interact);

— the focus on sustainable development (i.e., "green" goals should be inherent to publicly funded projects);

- the focus on the development of entrepreneurship;

- the orientation toward the development of civic society;

- openness and transparency as well as public accountability,

- the efficiency of functioning, which requires professional staff and the development of monitoring indicators and procedures;

- universality, which is the ability to satisfy the needs of services for all innovation actors.

In our opinion, the most desirable model for the State Agency for Innovation and Development creation is the joint action of the MESU and the MEDTU, with the transfer of powers needed to implement the innovation and entrepreneurial policies (Chart 2). 
Problems of the Institutional-Legal and Organizational Provision...

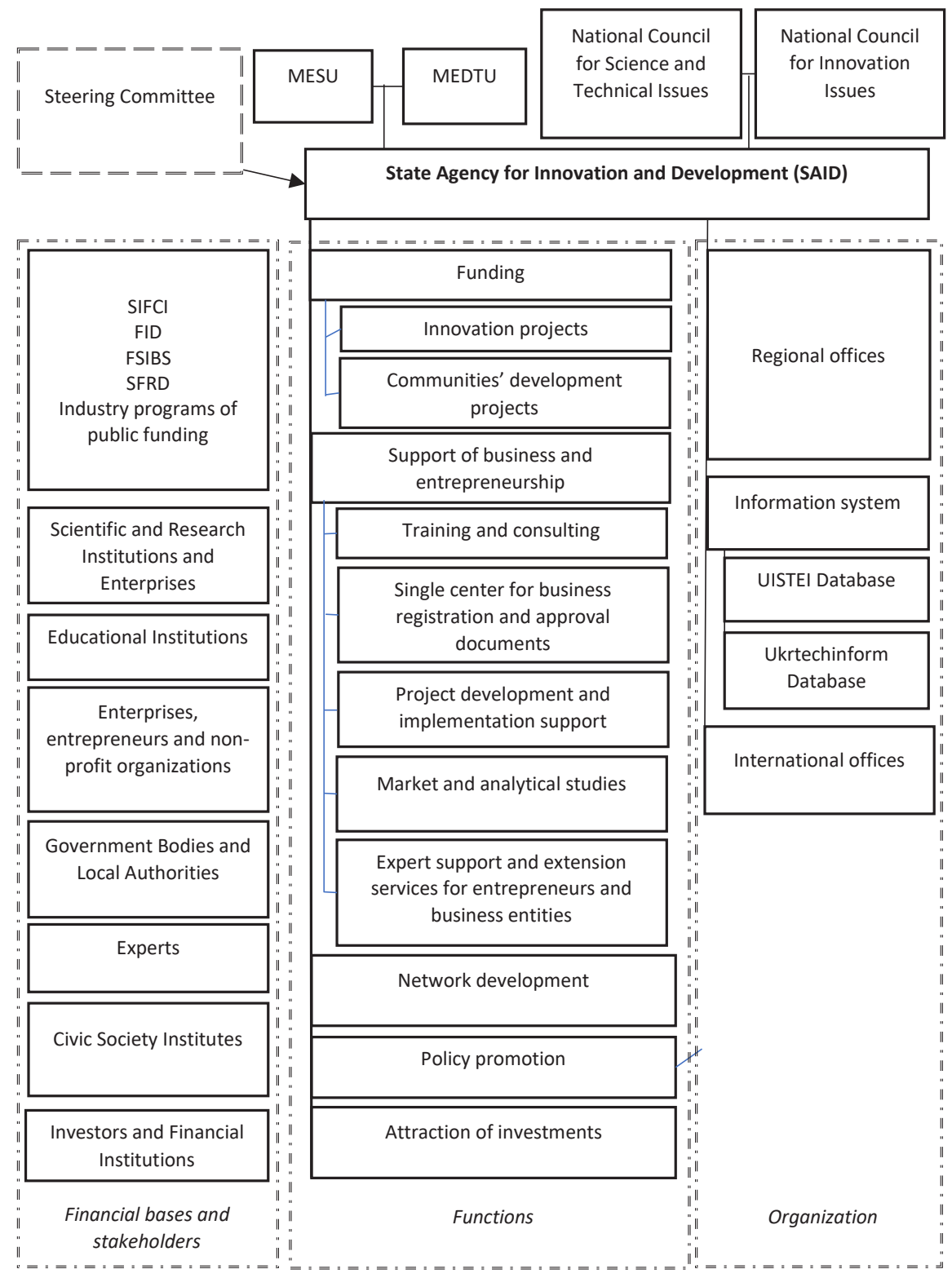

Chart 2. Organizational and functional facets of the State Agency for Innovation and Development operating in Ukraine

Source: authors' own elaboration.

The creation of a steering committee, with the participation of representatives from all central executive bodies as well as members from public, business, scientific and expert areas, will ensure the transparency and efficiency of the Agency's performance. 
It is advisable to authorize the Agency to make decisions regarding state funds (e.g., SIFCI, FID, FSIBS, SFRD) and industries' funding programs in order to ensure the innovative and sustainable development focus of funded projects, the transparency of their selection and the efficiency of their implementation. They should also create a sufficient financial basis for the Agency's functioning. In this case, one should point out the necessity to define funding quotas for different types of projects, industries, regions and business forms, when planning the Agency's activities for the medium and short term. It should ensure the balance of interests between those parties and that they correspond with national innovation development priorities.

From the functional point of view, the Agency acts as an innovation intermediary providing demand articulation, network formation and the management of innovation processes (Klerkx \& Leeuwis 2009). Thus, the Agency's main activities should be centered around:

— organizing training (covering, for instance, business creation and management, start-ups, modern technologies and solutions for business, technological options for different industries, etc.);

- consulting on project development and management;

- project progress tracking, especially start-ups;

- searching for partners (investors, innovators) and network development;

- market research;

- simplified procedures for business registration and obtaining approval documents (one-stop-centers);

- providing extension services and expert support for business (e.g., economic efficiency of technological modernization, tax regimes, export operations), etc.

The localized character of knowledge and socio-economic interactions important for the development of innovation (Isaksen 2001) makes the creation of the Agency's regional offices necessary (Fedulova 2012). It will enable the integration of "top-down" political regulation, in particular, concerning nationally specified priorities and directions of innovation and regional development. The "bottom-up" local initiatives will create a common, single space for the science-government-business-community interactions and the more efficient use of the regions' economic potential and competitive advantages (Isaksen 2001). The proper administrative support provides the opportunity to assure the focus on innovation of the existing economic relations; they also make it possible to form new appropriate partnerships at the regional level (Cooke 2001).

The need to integrate the existing scientific-technical and technology information databases into a single system controlled by the Agency is obvious since there is a multitude of them and their functions overlap. Specifically, the MESU has already created various information databases aimed at making information on innovation and technologies more accessible. The most known are the following: the National Technology Transfer Network ${ }^{5}$, the information website of the State Enterprise called "the

5 http://www.nttn.org.ua (accessed: 9.09.2018). 
Ukrainian Institute for Scientific, Technical and Economic Information" (UISTEI) ${ }^{6}$, and the information website of the Ukrainian Integrated Technology Transfer System of the State Enterprise called "The Center for Scientific and Technical Information and Promotion of Innovative Development of Ukraine" ("Ukrtechinform") 7 . Those information systems do currently operate, although the relevance and the consistency of the presented data are not guaranteed. For example, the latest update on the website of the National Technology Transfer Network is dated 2013. The same is true for the website of the SE "Ukrtechinform," where the logo of the now-closed Agency is still used, and the latest news is dated 2016. Thus, creating a single information system should preclude users' confusion and facilitate the finding of the necessary information. Additionally, it is necessary in order to ensure the efficiency of public expenses in this area.

The activities of the Agency's international offices are important given the need to provide a unified policy in the field of international cooperation in the transfer of technology, in scientific-technical and innovation areas, as well as to attract foreign investment and venture capital to the Ukrainian economy.

\section{Conclusions}

The public element of the NIS determines the process of socio-economic development and technical changes (Mazzucato 2017); thus the government's main task is to direct these processes towards the "necessary," socially desirable direction in accordance with its global development priorities: sustainability, energy conservation, social equity, etc. (Lundin \& Serger Schwaag 2018). At the same time, the insufficient interpretation of the complex, comprehensive and interactive nature of innovation impedes the formation and implementation of an effective innovation policy in terms of the legislation and the appropriate organizational mechanisms adequacy, as the Ukrainian case shows. So, based on the conducted study results, one should mark the following directions of the Ukrainian innovation policy improvement.

The authentic interpretation of "innovation" and the IS approach concept is crucial for building a comprehensive policy that will promote innovation and facilitate innovation-based economic growth. Given that, there is a need to review the existing concept of the NIS development in Ukraine, in particular, the NIS definition and its structure with regard to the links between the NIS elements. Additionally, there is an urgent need to approve the Strategy of Innovation Development in Ukraine, which should correspond with Agenda 2030 (The Sustainable 2017) and reflect the goals of innovation development with emphasis on resource and energy conservation, the development of green technologies, and social innovations (Lundvall 2007; Lundin \& Serger Schwaag 2018).

6 http://www.uintei.kiev.ua (accessed: 9.09.2018).

7 http://innov.org.ua (accessed: 9.09.2018). 
In our opinion, the creation of a State Agency for Innovation and Development in Ukraine, responsible for innovation policy implementation, will contribute to the strengthening of the "linkages" component of the NIS, not least because taking charge of public funds, advisory activities and business support functions is currently spread among various Ministers. It will ensure the unity of scientific and economic policy, and the integration of NIS development goals in industrial and regional programs and modernization projects. The regional Agency's divisions will, in turn, serve as a "connecting element" in the development of regional IS as a platform for combining the interests of local authorities, businesses, academic institutions and society at the local level. It will the conformity of regional and national development goals, as well as the adequacy of the appropriate policies based on strong feedback mechanisms.

At the same time, the Agency's creation and functioning are somewhat challenging. There are many issues to be solved in this regard, specifically: the development of appropriate methodological support (for the selection and tracking of innovation projects), staff assistance, and even the revision of existing structure and the powers of the executive bodies at the national and local levels, etc. These challenges create opportunities for further scientific research in this area.

\section{References}

Asheim, B.T. \& Coenen, L.J (2006), Contextualizing regional innovation systems in a globalizing learning economy: on knowledge bases and institutional frameworks, 'Technology Transfer', Vol. 31, https://doi.org/10.1007/s10961-005-5028-0

Association Agreement between Ukraine, on the one hand, and the European Union, the European Atomic Energy Community and their Member States, on the other side, International document, a Statement Ratified by Law of Ukraine from 16 September 2014, \# 1678-VII.

Autio, E., Kenney, M., Mustar, Ph., Siegel, D. \& Wright, M. (2014), Entrepreneurial innovation: the importance of context, 'Research Policy', Vol. 43, Is. 7, http://dx.doi. org/10.1016/j.respol.2014. 01.015

Budget Code, the Law of Ukraine from 8 July 2010, \# 2456-VI.

Coenen, L., Asheim, B., Bugge, M.M. \& Herstad, S.J. (2016), Advancing Regional Innovation Systems: What Does Evolutionary Economic Geography Bring to the Policy, 'Environment and Planning C: Politics and Space', Vol. 35, Is. 4, https://doi. org/10.1177\%2F0263774X16646583

Cooke, P. (2001), Strategies for regional innovation systems: learning transfer and applications. Centre for Advanced Studies, Cardiff University, Cardiff.

Daniluk, A. (2017), Cooperation between Business Companies and the Institutions in the Context of Innovations Implementation. Procedia Engineering, 182, DOI: 10.1016/j. proeng.2017.03.138

European Innovation Scoreboard 2018: Ukraine profile (2018), European Commission, https://ec.europa.eu/docsroom/documents/30705 
Fagerberg, J. (2015), Innovation policy, national innovation systems and economic performance: in search of a useful theoretical framework, Working Papers on Innovation Studies 20150321, Centre for Technology, Innovation and Culture, University of Oslo.

Fedulova, L. (2012), Problems of forming the institutional environment of innovation systems in Ukrainian regions, 'Economic bulletin of the university', State higher educational institution "Pereyaslav-Khmelnytsky State Pedagogical University named after Grigory Skovoroda”, Vol. 18-1.

Feinson, S. (2003), National Innovation Systems Overview and Country Cases. Vol. 1, Sec. 1, Knowledge Flows and Knowledge Collectives: Understanding the Role of Science and Technology Policies in Development. Center for Science, Policy and Outcomes, Columbia University.

Hladchenko, M. \& Pinheiro, R. (2018), Implementing the Triple Helix Model: Means-Ends Decoupling at the State Level?, 'Minerva', https://doi.org/10.1007/s11024-018-9355-3

Isaksen, A. (2001), Building regional innovation systems: is endogenous industrial development possible in the global economy?, 'Canadian Journal of Regional Science', 24 (1).

Issues of the Ministry of Economic Development and Trade, the Resolution of the Cabinet of Ministers of Ukraine from 20 August 2014, \# 459.

Issues of the State Innovation Finance and Credit Institution, the Resolution of the Cabinet of Ministers of Ukraine from 13 April 2000, \# 654.

Jurkovičová, L., Kubiniy, N. \& Hotra, V. (2014), The role of the state in the sphere of innovative development of the agricultural complex of Ukraine, 'Studia commercialia Bratislavensia', Vol. 7, No. 27, DOI: 10.2478/stcb-2014-0034

Kasych, A.O. \& Vochozka, M. (2017), Conceptual provisions of the development of Ukrainian national innovation system, 'Scientific bulletin of Polissia', No. 2 (10), DOI: 10.25140/2410-9576-2017-2-2 (10)16-23

Khaustova, K.M. (2016), Estimation the impact of macroeconomic factors on the innovation activities of enterprises in Ukraine, 'Marketing and Management of Innovations', Vol. 3.

Klein Woolthuis, R.J.A., Lankhuizen, M., \& Gilsing, V. (2005), A system failure framework for innovation policy design, 'Technovation', 25 (6). DOI: 10.1016/j.technovation.2003.11.002

Klerkx, L. \& Leeuwis, C. (2009), Establishment and embedding of innovation brokers at different innovation system levels: insights from the Dutch agricultural sector, 'Technological Forecasting \& Social Change', Vol. 76, DOI: 10.1016/j.techfore.2008.10.001

Lundin, N. \& Serger Schwaag, S. (2018), Agenda 2030 and A Transformative Innovation Policy - Conceptualizing and experimenting with transformative changes towards sustainability, Work in process WP 2018-01. Lund University.

Lundvall Bengt-Åke (2007), National innovation systems-analytical concept and development tool, 'Industry and innovation', Vol. 14, No. 1. https://doi. org/10.1080/13662710601130863

Maloney, W.F. (2017), Revisiting the national innovation system in developing countries (No. 8219). The World Bank. 
Martin, S. \& Scott, John T. (2000), The nature of innovation market failure and the design of public support for private innovation, 'Research Policy', No. 29.

Mazzucato, M. (2017), Mission-oriented Innovation Policy: Challenges and Opportunities. UCL Institute for Innovation and Public Purpose Working Paper Series, (IIPP 2017-01), https:// www.ucl. ac.uk/bartlett/public-purpose/wp2017-01 (accessed: 29.08.2018)

On Agricultural Advisory Activities, the Law of Ukraine from 17 June 2004, \# 1807-IV.

On Approval of the Concept for the Development of the National Innovation System, Order of the Cabinet of Ministers of Ukraine from 17 June 2009 \# 680-p

On Creation of the State Innovation Non-Bank Finance and Credit Institution «Fund for Support of Small Innovation Business», the Resolution of the Cabinet of Ministers of Ukraine from 12 December 2011, \# 1396.

On Innovation Activity, Law of Ukraine from 4 July 2002, \# 40-IV

On Scientific and Scientific-Technical Activity, the Law of Ukraine from 26 November 2015, \# 848-VIII.

On State Budget of Ukraine for 2018, the Law of Ukraine from 7 December 2017, \# 2246-VIII.

On State Regulation of Activity in the Technology Transfer Area, the Law of Ukraine from 14 September 2006, \# 143-V.

On Strategy of Sustainable Development “Ukraine - 2020”, Decree of the President of Ukraine from 12 January 2015, \# 5/2015.

On Ukrainian Fund for Entrepreneurship Support, the Resolution of the Cabinet of Ministers of Ukraine from 27 August 1995, \# 687.

Raven, R. \& Walrave, B. (2018), Overcoming transformational failures in the dynamics of technological innovation systems, 'Technological Forecasting and Social Change' (in press), https://doi.org/10.1016/j.techfore.2018.05.008

Regulation on the Ministry of Education and Science of Ukraine, the Resolution of the Cabinet of Ministers of Ukraine from 16 October 2014, \# 630

Report on the results of monitoring of SFRD projects in 2015-2017 (2018). U-Lead with Europe.

Some issues of the state fund of regional development, the Resolution of the Cabinet of Ministers of Ukraine from 18 March 2015, \# 196.

The 'Sustainable Development Goals: Ukraine' national baseline report (2017). Ministry of Economic Development and Trade of Ukraine, Kyiv.

Verspagen, B., Hollanders, H. \& Noben, L. (2018), Synthesis report on European innovation system. UNU-MERIT.

Wieczorek, A.J. \& Hekkert, M.P. (2012), Systemic instruments for systemic innovation problems: a framework for policy makers and innovation scholars, 'Science and Public Policy', 39.

Yegorov, I. \& Ranga, M. (2014), Innovation, politics and tanks: the emergence of a Triple Helix system in Ukraine and the influence of EU cooperation on its development, 'International Journal of Transitions and Innovation Systems', Vol. 3, No. 3, https:// doi.org/10.1504/IJTIS.2014.065700

Zakharchenko, N.V. \& Kuznietsov, E.A. (2017), The formation of the national innovation system as the basis of innovative-investment development in Ukraine, 'BUSINESSINFORM', No. 10. 


\section{Streszczenie}

\section{Problemy instytucjonalno-prawne i organizacyjne zapewnienia systemowej polityki innowacji: przypadek Ukrainy}

W artykule dokonano analizy „systemowego" wymiaru istniejących instytucjonalno-prawno-organizacyjnych osobliwości polityki innowacyjnej na Ukrainie, w oparciu o podejście SI (SI - System Innowacji), które jest uważane za jedną z głównych wytycznych dla kształtowania polityki innowacyjnej, w tym w szczególności również na Ukrainie. Stwierdzono, że państwowe dokumenty strategiczne w niewystarczający sposób odzwierciedlają systemowy charakter NSI (NSI - Narodowy System Innowacji), ani też nie sytuują powiązań ani przedsiębiorstw w centrum narodowego systemu innowacji. Określono obszary, w których polityka innowacyjna nie może być w pełni realizowana ze względu na obecny sposób organizacji działań i uprawnienia centralnych organów wykonawczych w tej dziedzinie, a w szczególności na ich wpływ na biznes, tworzenie infrastruktury i rozwój powiązań. Przedmiotem analizy są doświadczenia krajów europejskich w zakresie wdrażania polityki innowacyjnej, w szczególności w zakresie tworzenia i funkcjonowania modeli krajowych agencji innowacji, a także spektrum ich funkcji. W oparciu o doświadczenia europejskie proponuje się utworzenie Państwowej Agencji ds. Innowacji i Rozwoju na Ukrainie, która będzie integrować funkcje finansowania projektów regionalnych, udzielać porad i realizować podstawowe funkcje instytucji wspomagającej innowacje.

Słowa kluczowe: innowacje, system innowacji, instytucje wprowadzające innowacje, instytucje wspomagające innowacje, polityka innowacyjna 